\title{
ECONOMIC DEVELOPMENT AS A MATTER OF POLITICAL GEOGRAPHY
}

\author{
Jorge M. STREB* \\ PABLO F. DRUCK
}

\begin{abstract}
Can limited government be a driving force of economic development? This idea goes back to Montesquieu, and is closely related to recent research in institutional economics. Measuring limited government with the Henisz political constraints index, and economic development with income per capita, the paper first does a causality test to see whether political constraints lead income per capita. Since both are persistent variables, their differences are analyzed. The evidence from the 1960-1990 period indeed suggests that increases in political constraints precede economic growth. The effect of political constraints might take a long time period to set in, so a second test looks at the link between income per capita and polity persistence, conditioned on the degree of political constraints. Polity persistence is positively linked to income per capita with high political constraints, but there is no link with low political constraints. This broader evidence suggests that limited government has been conducive to economic development over the long run.
\end{abstract}

\section{Resumen}

¿El gobierno limitado lleva al desarrollo económico? Esta idea se encuentra en Montesquieu, y está estrechamente relacionada a investigaciones recientes en economía institucional. Midiendo gobierno limitado con el índice de contrapesos políticos de Henisz, y desarrollo económico con el ingreso por habitante, el trabajo primero estudia la relación de causalidad, viendo si los contrapesos políticos anticipan el ingreso por habitante. Dado que ambas son variables persistentes, se analizan sus diferencias. La evidencia del período 1960-1990 efectivamente sugiere que aumentos en los contrapesos políticos

* Jorge M. Streb (corresponding author): Universidad del CEMA, Av. Córdoba 374, C1054AAP Buenos Aires, Argentina (jms@cema.edu.ar). Pablo F. Druck: Universidad del CEMA, Av. Córdoba 374, C1054AAP Buenos Aires, Argentina (pd@ cema.edu.ar). Conversations with Jorge Avila, Roberto Cortés Conde, Mauricio Drelichman, Matías Iaryczower, Daniel Lema, Sebastián Saiegh, Walter Sosa Escudero, Pablo Spiller, Raúl Susmel, Mariano Tommasi, Gustavo Torrens, and Jeffrey Wilder were extremely helpful. We thank comments by Kurt Annen, Marcelo Delajara, Ignacio Esponda, Federico Weinschelbaum and participants at the ISNIE Conference in Tübingen, the AAEP Reunion in Córdoba, and seminars at CEDI, UNT, UNLP and UdeSA. We appreciate the research assistance of Julián Cristiá and the financial support of UCEMA. 
preceden al crecimiento económico. Como el efecto de los contrapesos políticos puede llevar un período largo en hacerse sentir, en segundo lugar se contrasta el nexo entre ingreso por habitante y persistencia del sistema político, condicionado al grado de contrapesos políticos. La persistencia del sistema político está positivamente ligada a ingreso por habitante cuando hay altos contrapesos políticos, pero no hay relación alguna cuando son bajos. Esta evidencia más amplia apunta en la dirección de que, en el largo plazo, el gobierno limitado ha conducido al desarrollo económico.

Key words: limited government, political constraints, polity persistence, economic development, income per capita.

JEL Classification: $011,057, P 16$.

"Democracy and aristocracy are not free states by their nature. Political liberty is found only in moderate governments ... So that one cannot abuse power, power must check power by the arrangement of things." Montesquieu, The Spirit of the Laws, Book 11.

\section{INTRODUCTION}

The question of economic development as a matter of political geography is motivated by the examples in Olson (1996), who vividly illustrates how political institutions may determine whether a country is rich or poor. He points to the contrasts between East and West Germany, and North and South Korea. Despite a common heritage and similar endowments, these countries had tremendously different economic performances. In both cases, the key difference was a political frontier.

The objective of this paper is to empirically study the causality between political institutions and economic development. Unlike most of the econometric literature, this paper does not focus on the influence of political institutions on the rate of growth, but rather on income per capita, the main indicator of whether a country is developed or not. Another difference is that we focus on one specific institutional characteristic, limited government. ${ }^{1}$

1 Econometric studies have extensively analyzed the influence of political variables on economic growth, as reflected in Barro and Sala-i-Martin (1995), who look at the influence of democracy and institutional quality on growth. The results show that political characteristics and political instability affect the underlying rate of growth, though the evidence is not robust (see, e.g., survey in Aron 2000). Henisz (2000), who develops the political constraints index as an objective measure of political institutions, finds that political constraints have a significant impact on growth rates; Drelichman (2001) finds that the influence of political constraints on growth is positive but non-linear. In contrast to this econometric literature, Streb (2001) argues that political institutions affect income per capita, rather than the growth rate. The logic is simple: if political institutions affect the degree of country risk, this will affect the capital stock per capita, that determines in turn income per capita. We follow this lead, which implies instead that changes in political institutions affect growth. 
Institutions are, in North's (1990, p. 3) terms, the rules of the game. Rules not only shape incentives and the timing of the moves, they determine who the relevant players are. The basic political rule can be reduced to the number of players that have a voice in political issues, abstracting from all aspects except the degree of checks and balances that the executive power faces.

The degree of checks and balances can be represented by the political constraints variable constructed by Henisz (2000), which captures the number of veto players in a political system. This paper specifically focuses on the causality between political constraints, characteristic of limited government, and economic development. If limited government is favorable for sustained economic growth, one would expect countries with political constraints to have their successful growth record reflected in high relative income levels. ${ }^{2}$

The specific role of limited government as a precondition for economic growth was brought to prominence by the path-breaking work of North and Thomas (1973) in economic history. This idea can be traced back at least to Montesquieu, with his emphasis on checks and balances to executive power as the way to assure political and economic liberties, which enable personal and societal development.

Our focus on limited government as a path to economic development may appear a bit one-sided, taking into account that North (1990, pp. 47/8) himself stresses that though political rules are hierarchically prior to property rights and individual contracts, as far as causality is concerned the influence may run both ways. Moreover, North (1990, p. 101) downplays the role of basic political rules, in his contrast of the success of the United States with the failures of the Latin American countries, which tried to adopt the U.S. Constitution in the nineteenth century. Although the rules may have been similar, enforcement, norms of behavior and the subjective models of the players differed. ${ }^{3}$

We control for North's enforcement problem by using a measure of polity persistence from the Polity Project. Insofar as a country can stick to limited government, under those conditions one might expect a more clear-cut positive relationship between limited government and economic development, because actual enforcement is crucial for limited government to be effective and last. That is, if limited government stays in place, it must mean that is being enforced, otherwise, it would degenerate into autocracy (Olson 2000, p. 41, makes this point nicely).

Moreover, the details of an institutional system are not ready when it has been first set down. As the Federalist Papers remark of the U.S. Constitution, what the constitution states has to be filled in with government practice, as well as with the interpretation of constitutional rights and obligations by courts. The

2 Developed countries do not tend to have high growth rates; rather, countries with the highest current growth rates are typically less developed countries that are catching up (Streb 2001). This effect is controlled for in growth regressions by including an extra term for initial income per capita in the period under study.

3 North stresses the underlying influence of ideology. North (1990, pp. 12 and 28) interprets Coase (1960) in the sense that, when it is costly to transact, the structure of property rights matters. With the high transactions costs of political markets, and the subjective perceptions of the actors, inefficient property rights that do not induce economic growth may result (North 1990, p.52). 
effects of limited government also take time to set in. Like Rome, successful societies are not built in a few years.

Section 2 briefly reviews some of the literature on the role of limited government in determining property rights, which are essential for markets to work. Section 3 describes the dataset. Section 4 explores the implication that larger political constraints lead to higher income per capita. Granger causality tests of the differences of these variables in the 1960-1990 period show that changes in political constraints indeed precede income growth. Section 5 looks at the correlation between polity persistence, a measure of the years the current political authority structure has been in place, and income per capita. This correlation is positive with high political constraints, but it breaks down with low political constraints. This evidence suggests that, in the long run, limited government is a path (though not necessarily the path) to economic development. Section 6 concludes.

\section{LIMITED GOVERNMENT AS THE FOUNDATION OF PROPERTY RIGHTS}

Property rights are essential for economic exchange and markets. Consequently, the laws and regulations that determine property rights are relevant for economic performance. In turn, political institutions are the foundation of other institutions, because they determine the legal rules that govern property rights. Our focus here is on how basic political institutions affect the economy. In this vein, North (1981, p. 21) analyzes how the state, an organization with a comparative advantage in violence, is in the position to specify and enforce property rights.

That politics is at the bottom of property rights goes back a long way. Smith (1976 [1776], vol. 2, p. 232) views the protection of private property as the reason for civil government. Marx made variations of this theme famous. ${ }^{4}$ However, in Marx's view economic forces shape political development, which is a mere superstructure that reflects the underlying economic structure.

It is in Montesquieu that the influence of the political system on the economy forms a centerpiece. ${ }^{5}$ Montesquieu (1989 [1748], p. 10) distinguishes between three kinds of government: despotism, monarchy and republic. He makes it clear that property rights inherently rest on the decisions of political power, and these political foundations may be very flimsy. He writes in Book 5, p. 61, of the Ottoman Empire that

4 For example, in the 1848 The Communist Manifesto (cf. Tucker 1972), Marx and Engels depict the state as a committee for protecting the class interests of the bourgeoisie. Political power is merely the organized power of one class, the bourgeoisie that own the capital, for oppressing another, the proletariat that works.

5 Though his ideas on constitutional design have recently started to be rescued in political economics, Montesquieu is ignored in practically all histories of economic thought. An important exception is Hirschman (1996 [1976]). However, Hirschman stresses that Montesquieu, as well as other eighteenth century writers, expected economic expansion to improve the political order. We disagree. This is a completely secondary theme in The Spirit of the Laws. More importantly, Montesquieu did not believe that economic selfinterest was enough to moderate political ambition; only political checks and balances could do that job. Instead, the main theme in Montesquieu is how limited government can improve the political order, and by extension lead to economic expansion. 
"Of all despotic governments, none is more oppressive to itself than the one whose prince declares himself the owner of all the land and heir to all his subjects ... In these states, nothing is repaired, nothing improved."

Montesquieu has a more positive view of monarchies, where one alone governs subject to fixed and established laws. Nevertheless, his praise is mainly reserved for republics, i.e., democracies and aristocracies. Book 20, pp.340/1, states that

"Commerce is related to the constitution ... great commercial enterprises are not for monarchies, but for the government by many. In short, one's belief that one's prosperity is more certain in these states makes one undertake everything, and because one believes that what one has acquired is secure, one dares to expose it in order to acquire more; only the means for acquisition are at risk; now, men expect much of their fortune."

Furthermore, Montesquieu points out in Book 11 that liberty is not the creature of democracy and aristocracy by itself, but rather of limited government (the quote that heads this paper). Book 11 makes it clear that separation of powers, with the appropriate checks and balances, is required to assure liberty, and with it other basic rights of individuals like property rights. Combined with the statement in Book 20 that accumulation is the consequence of secure property rights in republics, one can say that the republics that foster economic accumulation in Montesquieu are those that have moderate government. This is at the heart of the hypothesis we are analyzing in this paper.

North and Thomas (1973, p. 157) highlight the historical importance of the development, in the sixteenth and seventeenth centuries, of property rights in the Netherlands and England. These property rights raised the private rate of return on innovation and productive activity. North and Thomas emphasize that the development of property rights was prior to the industrial revolution in the eighteenth century, and that these institutional changes paved the way for the technological revolution that ensued.

The fact that the crowns in the Netherlands and England had to grant representative bodies control over tax rates is a key factor in the development of these property rights. North (1980, pp. 147/57), summarizing the evidence in North and Thomas (1973), contrasts the moderating role of the States General in the Netherlands and the Parliament in England to the Cortes in Spain and the Estates General in France, which surrendered the power to tax to the crown. The absolute tax power of the crowns in Spain and France implied they had the exclusive right to alter property rights. Together with the fact that the crowns could grant inefficient monopoly privileges, these absolute powers stifled economic growth in Spain and France.

North and Weingast (1989) analyze the development of the capital market in England after the elimination, with the 1688 Revolution, of the arbitrary and confiscatory power of the English Crown. The capital market is, of course, an essential pre-requisite for the large-scale capital investment that were required by the industrial revolution.

Olson (2000, pp. 185/7) links the dilemma between achieving high or low income per capita to the existence or not of well-developed capital markets. While spot markets can thrive under almost any circumstances, capital markets involve 
transactions where something is given now in exchange for a promise in the future. A developed capital market thus requires a legal system that ensures these contracts are enforced. In turn, for Olson (2000, pp. 35/6) a legal system that protects property rights requires a political system that limits the power of the executive through power sharing. We now explore the role of limited government. ${ }^{6}$

\section{Dataset}

To explore the link between limited government and economic development across countries, we use one economic variable, income per capita, and two political variables, political constraints and polity persistence.

The income per capita data is from the Penn World Table, and covers the 1960-1990 period. Income per capita is in constant US dollars, at 1985 international prices. In the Penn World Table, income per capita is adjusted by purchasing-power parity (p.p.p.) to improve international income comparisons.

The political constraints (POLCON) index is from Henisz (2000). The POLCON index takes into account the number of veto points faced by the executive power, as well as the distribution of political preferences across different branches of government. More alignment across branches of government increases the feasibility of policy change and implies less political constraints for the executive. The political constraints measure is derived in a spatial model under the assumption that the status quo policy is uniformly distributed over the policy space $[0,1]$. The minimum is a value of 0 , which implies no constraints and absolute political discretion for the executive. With a single legislative chamber, POLCON may reach a maximum of $2 / 3$ when the legislative branch is in hands of the opposition, while with two chambers the maximum is $4 / 5$, when neither of the chambers is aligned with the executive. ${ }^{7}$ POLCON counts an independent judiciary power and the presence of sub-federal branches of government as additional veto players, reaching a maximum value of $19 / 21 .^{8}$

The Polity Project was originally designed to facilitate the study of regime persistence and change; more recently, it has been altered for use in longitudinal

6 There is a literature on the determinants of financial development, measured by alternative ratios of bank and corporate debt to GNP, and of stock market capitalization to GNP. La Porta et al. (1997) find that the size of a country's capital markets depends on both legal rules and their enforcement. Beck et al. (2001) incorporate political variables. Once they control for the impact of income per capita, current political structure is not significant. However, this literature does not deal with the issue of the influence of political institutions on income per capita, which might be the channel by which politics affects financial development.

7 Henisz (2000) additionally considers the distribution of preferences within different branches, because a more fractionalized opposition has less power to check the executive.

8 Drelichman (2001) finds that over $45 \%$ of the POLCON observations are concentrated at zero, corresponding to political systems with an unchecked executive power (dictatorships, absolute monarchies and other autocracies), $30 \%$ of the observations have values between 0.7 and 0.9 (a value of $2 / 3$ or more corresponds to one or more veto points), while the remaining observations fall in between (they correspond to political systems with around one or less than one effective veto point, where other branches of government are aligned with the executive). 
studies of political behavior. The data on polity persistence originated from the Polity II database elaborated by Gurr (1989), later updated to 1994. A polity comprises the basic political arrangements by which countries govern their affairs, namely its structures of rule-making, rule-application and the relations with citizens or subjects. Polity persistence is a measure, in years, of the current age of a polity, i.e. the number of years since the last major, abrupt Polity Change. A Polity Change occurs when there is a change in the authority structure, i.e. a change in: (a) executive recruitment (regulated or not, e.g., elections versus coups); (b) executive constraints (e.g., the establishment of an independent legislature); (c) political participation (competitive or not); (d) centralization of political authority (unitary or federal state); (e) type of executive (individual or collective); and (f) scope of government activities (basic security and justice versus totalitarian state).

Table 1 presents the averages, over the 1960-1990 period, of income per capita, polity persistence, and political constraints. These averages correspond to a reduced sample of 62 countries whose information is available for the complete period. The countries are divided into two groups, low and high political constraints (POLCON).

In the sections below we analyze the interrelationship between these variables. For the moment, we only want to point out that, in Table 1, countries with high political constraints have higher income per capita and higher polity persistence. Political constraints have a strong positive correlation with income per capita in the yearly data. ${ }^{9}$ Gaviria et al. (1999) note that the Henisz POLCON variable is more in line with the relative income per capita of the different regions than other measures of institutional development in the literature, such as the ICRG indexes used by Burki and Perry (1998) that reflect opinions on the protection of property rights and on corruption. In our view, political constraints are the fundamental measure of political institutions of a country.

Table 2 presents data for 1986, when information on 124 countries is available. In comparison to the total sample, the income, polity persistence and

TABLE 1

DATA FOR REDUCED SAMPLE OF 62 COUNTRIES, 1960-1990 AVERAGES

\begin{tabular}{|c|c|c|c|c|c|c|c|c|}
\hline \multicolumn{3}{|c|}{$\begin{array}{c}\text { GDP per capita } \\
\text { (U.S. dollars at 1985 prices) }\end{array}$} & \multicolumn{3}{c|}{ Polity persistence } & \multicolumn{3}{c|}{ Political constraints } \\
\hline Total & $\begin{array}{c}\text { Low } \\
\text { POLCON }\end{array}$ & $\begin{array}{c}\text { High } \\
\text { POLCON }\end{array}$ & Total & $\begin{array}{c}\text { Low } \\
\text { POLCON }\end{array}$ & $\begin{array}{c}\text { High } \\
\text { POLCON }\end{array}$ & Total & $\begin{array}{c}\text { Low } \\
\text { POLCON }\end{array}$ & $\begin{array}{c}\text { High } \\
\text { POLCON }\end{array}$ \\
\hline 5135 & 2309 & 7960 & 38 & 14 & 62 & 0.45 & 0.14 & 0.77 \\
\hline
\end{tabular}

Notes: GDP per capita is from the Penn World Table, in constant U.S. dollars at 1985 international prices (adjusted for p.p.p.). Polity persistence is from Gurr (1989), updated to 1994. Political constraints are from Henisz (2000).

9 For example, the coefficients of correlation between political constraints and the log of income per capita are 0.72 in $1960,0.73$ in 1975 and 0.77 in 1990. 
TABLE 2

DATA FOR REDUCED SAMPLE COMPARED TO TOTAL SAMPLE, 1986

\begin{tabular}{|l|c|c|c|c|c|c|c|c|c|}
\hline Averages of & \multicolumn{3}{|c|}{$\begin{array}{c}\text { GDP per capita } \\
\text { (U.S. dollars at 1985 prices) }\end{array}$} & \multicolumn{3}{|c|}{ Polity Persistence } & \multicolumn{3}{c|}{ Political Constraints } \\
& Total & $\begin{array}{c}\text { Low } \\
\text { POLCON }\end{array}$ & $\begin{array}{c}\text { High } \\
\text { POLCON }\end{array}$ & Total & $\begin{array}{c}\text { Low } \\
\text { POLCON }\end{array}$ & $\begin{array}{c}\text { High } \\
\text { POLCON }\end{array}$ & Total & $\begin{array}{c}\text { Low } \\
\text { POLCON }\end{array}$ & $\begin{array}{c}\text { High } \\
\text { POLCON }\end{array}$ \\
\hline Reduced sample & 6345 & 2776 & 9913 & 44 & 18 & 71 & 0.49 & 0.21 & 0.77 \\
Total & 4470 & 1958 & 6983 & 32 & 18 & 45 & 0.32 & 0.01 & 0.63 \\
Reduced/total & 1.42 & 1.42 & 1.42 & 1.40 & 0.98 & 1.57 & 1.53 & 24.04 & 1.22 \\
\hline
\end{tabular}

Notes: GDP per capita is from the Penn World Table, in constant U.S. dollars at 1985 international prices (adjusted for p.p.p.). Polity persistence is from Gurr (1989), updated to 1994. Political constraints are from Henisz (2000).

TABLE 3

NUMBER OF COUNTRIES BY GEOGRAPHIC REGION, 1986

\begin{tabular}{|l|c|c|c|c|c|c|c|c|c|c|}
\hline Region & $\begin{array}{c}\text { North } \\
\text { America }\end{array}$ & Europe & Oceania & $\begin{array}{c}\text { Latin } \\
\text { America }\end{array}$ & $\begin{array}{c}\text { Sub- } \\
\text { Saharan } \\
\text { Africa }\end{array}$ & Caribbean & $\begin{array}{c}\text { NE } \\
\text { Asia }\end{array}$ & $\begin{array}{c}\text { SE } \\
\text { Asia }\end{array}$ & $\begin{array}{c}\text { Middle East } \\
\text { \& North } \\
\text { Africa }\end{array}$ & Total \\
\hline Reduced sample & 2 & 21 & 2 & 16 & 6 & 1 & 2 & 5 & 7 & 62 \\
Total & 2 & 25 & 2 & 18 & 42 & 4 & 6 & 8 & 17 & 124 \\
Reduced/Total & 1 & 0.84 & 1 & 0.89 & 0.14 & 0.25 & 0.33 & 0.63 & 0.41 & 0.50 \\
\hline
\end{tabular}

Notes: for reduced sample, NE Asia is Japan and Taiwan; SE Asia is India, Indonesia, Malaysia, Philippines and Thailand; Middle East \& N. Africa is Egypt, Israel, Jordan, Morocco, Pakistan, Tunisia and Turkey. The classification is taken from the World Bank web page: www.worldbank.org/aidsecon/arv/floyd/whoarv-webp12.htm.

political constraints of countries in the reduced sample are higher (compared to the complete sample, all countries in the reduced sample have relatively high political constraints).

Table 3 shows the classification of the countries available in 1986 by geographic region. The most severely underrepresented countries in the reduced sample are from Sub-Saharan Africa.

\section{Causality tests}

Does moderate government and constitutional democracies lead to economic development? To address the problem that political institutions can depend endogenously on economic development, we first look at the causality between political constraints and income per capita.

Political constraints and income per capita are both statistically persistent variables, so we difference both. In differences, our hypothesis implies that changes in political institutions drive economic growth. We took the reduced sample of 62 
countries available over the whole 1960-1990 period in the Penn World Table. To carry out Granger causality tests, the data set is divided in two periods, 19601975 and 1975-1990, since we are interested in capturing long-term effects.

Table 4 shows the changes in political constraints, POLCON, in response to changes in the log of income per capita, $\ln (\mathrm{Y} / \mathrm{L})$. According to the results in Table 4, growth does not precede changes in political constraints in our reduced sample of countries. When we control for past changes of POLCON (i.e., changes in the 1960-75 period), the result on the insignificance of past growth in explaining changes in political constraints is not affected.

Table 5 shows the inverse relationship, how economic growth responds to changes in political constraints. Changes in political constraints are significant in the regression, preceding economic growth. When we control for growth in the 1960-75 period, results remain unaltered.

TABLE 4

GRANGER CAUSALITY TEST: $\triangle$ POLCON 75-90 AS DEPENDENT VARIABLE

\begin{tabular}{|l|c|c|}
\hline & Test 1 & Test 2 \\
\hline$\Delta \ln ($ Y/L) 60-75 & -0.0621 & -0.0478 \\
& $(-0.791)$ & $(-0.632)$ \\
POLCON 60-75 & & -0.3148 \\
& & $(-2.462)^{* *}$ \\
Constant & 0.1158 & 0.1013 \\
& $(2.817)^{* * *}$ & $(2.538)^{* *}$ \\
Adjusted R & -0.0062 & 0.0721 \\
F statistic & 0.625 & $3.37 * *$ \\
P-value (F statistic) & 0.432 & 0.041 \\
Observations & 62 & 62 \\
\hline
\end{tabular}

Note: t-statistics in parenthesis. One, two and three asterisks indicate significance at $10 \%, 5 \%$ or $1 \%$.

TABLE 5

GRANGER CAUSALITY TEST: $\triangle$ LN(Y/L) 75-90 AS DEPENDENT VARIABLE

\begin{tabular}{|l|c|c|}
\hline & Test 1 & Test 2 \\
\hline$\Delta$ POLCON 60-75 & 0.6440 & 0.6159 \\
& $(2.808)^{* * *}$ & $(2.713)^{* * *}$ \\
$\Delta \ln ($ Y/L) 60-75 & & 0.2163 \\
& & $(1.612)$ \\
Constant & 0.2534 & 0.1516 \\
& $(7.779)^{* * *}$ & $(2.139)^{* *}$ \\
Adjusted R & 0.1014 & 0.1247 \\
F statistic & $7.89 * * *$ & $5.35 * * *$ \\
P-value (F statistic) & 0.007 & 0.007 \\
Observations & 62 & 62 \\
\hline
\end{tabular}

Note: t-statistics in parenthesis. One, two and three asterisks indicate significance at $10 \%, 5 \%$ or $1 \%$. 
The experience of non-OECD countries drives the results in Table 5, since political constraints in OECD countries change very little over this period. In Section 5, we will look at a different test that takes into account the influence of OECD countries on long-run behavior.

The Granger causality tests in Tables 4 and 5 point in the direction that having more political constraints to executive power precedes increases in income per capita. These results run counter to some widespread views on the relation between economic development and political development, turning modernization theory, Marxism, and others on their head. They point in the direction that limited government leads to higher income per capita, i.e., that political development leads to economic development.

One of the limitations of these tests is that they look at relatively short time-span of 15 years. Furthermore, some of the changes in political constraints are not permanent, since they are reversed in the second half of the period (cf. Table 4). We now try to deal with these issues by using a variable of polity persistence.

\section{Polity Persistence And economic development}

We now turn to a more long-run perspective on the relation between limited government and economic development, using data on polity persistence. This allows to control for the problem of enforcement raised by North (1990) (cf. Introduction), that might turn constitutional restraints on executive power into mere pieces of paper.

If political constraints are indeed effective in checking executive power, an evidence of this is that the political structure will resist the passage of time, so for example a democratically elected president doesn't subsequently close Congress, ban political parties and becomes a dictator with absolute power.

Additionally, if limited government leads to economic development, as Section 4 suggests, one would expect this process to take time to unveil itself. The variable polity persistence gives us the needed time dimension, since it measures the number of years that the essential institutional authority properties last over time. This also allows to take advantage of the information from OECD countries that have not had major changes in political constraints in the 19601990 period.

Figure 1 shows a scatter diagram with the positive association of economic development and political constraints in $1960 .{ }^{10}$ The size of the bubbles

10 The figure, adapted from Streb (2001), is representative of other years. Streb (2001) finds a positive effect of a measure of the duration of political constraints, POLCON* $\ln (1+$ YEARS $)$, where YEARS represents the years of polity persistence, on $\ln (\mathrm{Y} / \mathrm{L})$, attributing this to an uncertainty channel: if a larger duration of political constraints implies lower political uncertainty, sovereign risk should be lower, so the country should receive a larger share of the available capital stock, achieving a higher relative income per capita. However, the direction of causality between political constraints and income per capita is not tested in that paper. 
FIGURE 1

RELATIVE INCOME PER CAPITA AND POLITICAL CONSTRAINTS, 1960 -SIZE OF BUBBLES REPRESENTS YEARS OF POLITY PERSISTENCE, AND LN $(\mathrm{Y} / \mathrm{L})_{\mathrm{USA}}=1-$

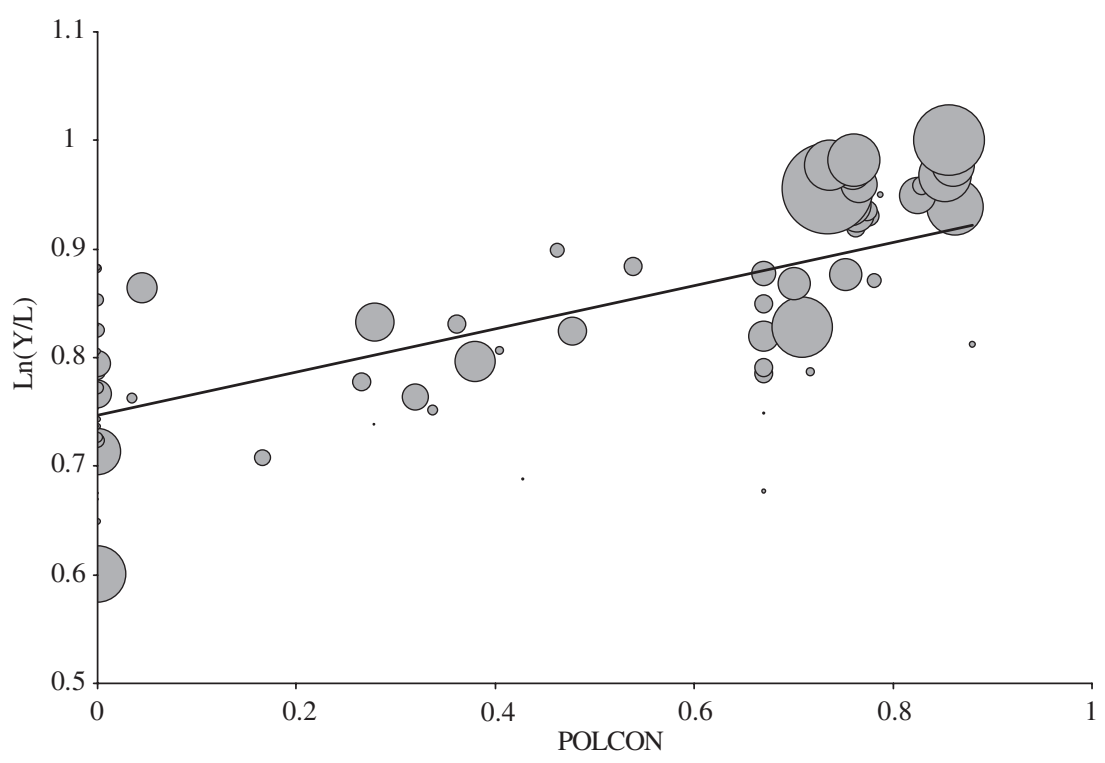

represents the years of polity persistence. When there are no political constraints at all, there is usually no clear pattern. Ethiopia was among the countries with no political constraints, and it was also the poorest nation in the Penn World Table in 1960. Until the 1974 coup, Ethiopia also had one of the most persistent political regimes. On the other hand, when there are positive political constraints, larger bubbles seem to drift up. If limited government leads to economic development, one can expect this pattern, since the process of development takes place over time.

To test non-parametrically if limited government has a positive influence on economic development, we stratify the data into two groups, low and high political constraints. We use the median of the sample to separate the two groups, unless more than half the countries in a given year have zero political constraints (in which case these are all classified as low political constraints). We create a contingency table, ranking the countries within each group according to their income per capita and their degree of polity persistence. We then carry out a chi-square test using these rankings (Rice 1995), to see whether polity persistence and income per capita are independent within each group.

Since we are focusing on long run relationships, in Table 6 we use the averages of income per capita (Y/L), political constraints (POLCON) and polity persistence (YEARS) for the reduced sample of 62 countries available over the whole 1960-1990 period. The contingency tables show that for countries with high POLCON there is indeed a positive association between Y/L and YEARS, 
TABLE 6

CONTINGENCY TABLES AND CHI-SQUARE TEST OF INDEPENDENCE USING 1960-1990 AVERAGES FOR REDUCED SAMPLE OF 62 COUNTRIES

\begin{tabular}{|l|c|c|c|}
\hline & $\begin{array}{c}\text { YEARS: } \\
\text { low }\end{array}$ & $\begin{array}{c}\text { YEARS: } \\
\text { high }\end{array}$ & Total \\
\hline POLCON: high & & & \\
Y/L: low & 13 & 3 & 16 \\
Y/L: high & 3 & 12 & 15 \\
Total & 16 & 15 & 31 \\
Chi-square statistic & 11.63 & & \\
P-value & $0.0006 * * *$ & & \\
\hline POLCON: low & & & 16 \\
Y/L: low & 9 & 7 & 31 \\
Y/L: high & 7 & 8 & \\
Total & 16 & 15 & \\
Chi-square statistic & 0.28 & & \\
P-value & 0.5967 & & \\
\hline
\end{tabular}

Note: Cut-off value of POLCON that divides into the groups with high and low political constraints is 0.59 . One, two and three asterisks indicate that null hypothesis of independence is rejected at $10 \%, 5 \%$ or $1 \%$ probability value.

whereas there is no relationship for countries with low POLCON (there are 31 countries in each group).

In the reduced sample there may be a sample selection bias problem, because the countries that have complete information for the whole period have higher political constraints, polity persistence and income per capita than the complete sample (cf. Table 2). Table 7 shows the result of chi-square tests of whether polity persistence and income per capita are independent once we condition for political constraints (dividing the countries into two groups with high and low political constraints), using yearly data for the complete sample. We do not show the contingency tables for each year, but they are qualitatively similar to results in Table 6 .

In most years of the sample, there is no relation at all between polity persistence and income per capita when there are low political constraints: there is a significant association in only 7 of the 31 years. On the other hand, there is a very robust relationship between polity persistence and income per capita when high political constraints exist: it is present every year, and in 28 of 31 years it is significant at the $1 \%$ level. Since the variables have a lot of persistence, not all of this yearly information provides new and independent information. However, Table 7 does show that the results are robust to including all the information available on the countries in the dataset.

These results do not mean that limited government by itself tells the whole story about economic development. First, the actual policies carried out within the basic political rules are crucial for performance. Second, there are countries 
like Korea that have achieved a relatively high income per capita, though limited government was not in place first. Rather, we interpret the results in the sense that a system of government that does not limit in a substantial way the power of the executive is not sure to achieve economic development.

In short, the results in Table 6 and 7 can be interpreted in the sense that limited government is $a$ path to economic development. Polity persistence seems to have a systematic beneficial effect on economic development once

TABLE 7

CHI-SQUARE TEST OF INDEPENDENCE USING YEARLY

DATA FOR WHOLE SAMPLE

\begin{tabular}{|c|c|c|c|c|c|c|}
\hline \multirow[t]{2}{*}{ Year } & \multirow{2}{*}{$\begin{array}{c}\text { Cut-off } \\
\text { value for } \\
\text { POLCON }\end{array}$} & \multicolumn{3}{|c|}{ Number of Countries } & \multirow{2}{*}{$\begin{array}{l}\text { P-value for } \\
\text { high } \\
\text { POLCON }\end{array}$} & \multirow{2}{*}{$\begin{array}{c}\text { P-value for } \\
\text { low } \\
\text { POLCON }\end{array}$} \\
\hline & & Total & $\begin{array}{c}\text { Low } \\
\text { POLCON }\end{array}$ & $\begin{array}{c}\text { High } \\
\text { POLCON }\end{array}$ & & \\
\hline 1960 & .37 & 76 & 38 & 38 & $0.0231 * *$ & 0.1049 \\
\hline 1961 & .26 & 85 & 43 & 42 & $0.0231 * *$ & 0.1049 \\
\hline 1962 & .26 & 91 & 46 & 45 & $0.0231 * *$ & 0.1049 \\
\hline 1963 & .25 & 93 & 45 & 48 & $0.0093 * * *$ & 0.1715 \\
\hline 1964 & .25 & 94 & 46 & 48 & $0.0015 * * *$ & $0.0404 * *$ \\
\hline 1965 & .25 & 98 & 49 & 49 & $0.0010 * * *$ & 0.4708 \\
\hline 1966 & .25 & 102 & 51 & 51 & $0.0033 * * *$ & 0.8875 \\
\hline 1967 & .26 & 103 & 52 & 51 & $0.0032 * * *$ & 0.3929 \\
\hline 1968 & .27 & 105 & 53 & 52 & $0.0009 * * *$ & 0.3247 \\
\hline 1969 & .26 & 105 & 53 & 52 & $0.0009 * * *$ & 0.8415 \\
\hline 1970 & .27 & 109 & 55 & 54 & $0.0011 * * *$ & 0.4839 \\
\hline 1971 & .16 & 110 & 55 & 55 & $0.0003 * * *$ & 0.5023 \\
\hline 1972 & 0 & 111 & 58 & 53 & $0.0002 * * *$ & 0.2835 \\
\hline 1973 & 0 & 111 & 59 & 52 & $0.0009 * * *$ & 0.2921 \\
\hline 1974 & 0 & 112 & 59 & 53 & $0.0002 * * *$ & 0.3566 \\
\hline 1975 & 0 & 114 & 61 & 53 & $0.0016 * * *$ & 0.2401 \\
\hline 1976 & 0 & 116 & 62 & 54 & $0.0004 * * *$ & 0.1738 \\
\hline 1977 & 0 & 115 & 60 & 55 & $0.0003 * * *$ & 0.2031 \\
\hline 1978 & 0 & 116 & 61 & 55 & $0.0003 * * *$ & 0.0538 \\
\hline 1979 & 0 & 116 & 62 & 54 & $0.0004 * * *$ & 0.1738 \\
\hline 1980 & 0 & 116 & 59 & 57 & $0.0001 * * *$ & 0.4795 \\
\hline 1981 & 0 & 117 & 60 & 57 & $0.0001 * * *$ & 0.2560 \\
\hline 1982 & 0 & 117 & 59 & 58 & $0.0001 * * *$ & 0.2367 \\
\hline 1983 & 0 & 117 & 60 & 57 & $0.0009 * * *$ & 0.1670 \\
\hline 1984 & 0 & 119 & 61 & 58 & $0.0001 * * *$ & $0.0783^{*}$ \\
\hline 1985 & 0 & 126 & 65 & 61 & $0.0014 * * *$ & $0.0248 * *$ \\
\hline 1986 & .21 & 124 & 62 & 62 & $0.0001 * * *$ & $0.0222 * *$ \\
\hline 1987 & .23 & 122 & 60 & 62 & $0.0001 * * *$ & $0.0213 * *$ \\
\hline 1988 & .34 & 118 & 59 & 59 & $0.0002 * * *$ & $0.0134 * *$ \\
\hline 1989 & .32 & 116 & 58 & 58 & $0.0000 * * *$ & $0.0660 *$ \\
\hline 1990 & .38 & 96 & 47 & 49 & $0.0000 * * *$ & 0.4463 \\
\hline
\end{tabular}

Note: One, two and three asterisks indicate that null hypothesis of independence is rejected at $10 \%$, $5 \%$ or $1 \%$ probability value. 
the correct political framework is in place, i.e., in countries with political constraints. ${ }^{11}$

\section{Conclusions}

According to modernization theory, popular in political science, democracy is an endogenous consequence of economic development. ${ }^{12}$ Here we do not look at the relationship between democracy and economic development. Rather, we look at the relationship between limited government and economic development.

We first focus on the causality between economic development and limited government. The Henisz (2000) political constraints index is used as a measure of limited government, and economic development is measured by income per capita.

It is important to bear in mind that political constraints do not merely refer to the difference between dictatorship and democracy. Not every democracy satisfies the characterization of limited government. Rather, a constitutional, or liberal, democracy that observes certain basic rights is required to have limited government. This point made by Montesquieu remains an important question nowadays (see, e.g., Nino 1996).

Since political constraints and income per capita are very persistent variables, we difference them, looking at the relationship between changes in the 19751990 period and changes in the 1960-1975 period. Our simple Granger causality tests show that changes in political constraints precede economic growth, but not the other way around. This points in the direction that political development causes economic development. This evidence is driven, basically, by developing countries, since OECD countries have very few changes in political constraints over this period. Moreover, since part of the changes in political constraints in the first half are reversed in the second half, this does not fully capture longterm effects.

To actually speak of the long-run consequences of limited government, it must be in place for long enough, because any institutional system takes time to settle in and show its consequences. Hence, a second test looks at the crosssectional relationship between polity persistence and income per capita, dividing the sample into two groups, countries with low or high political constraints. This non-parametric test shows that polity persistence does not have a robust positive relation to income with low political constraints, but that there is a strong positive relationship with high political constraints. This second evidence is driven mostly by OECD countries that are among the countries with the

11 Polity persistence does not give us the history before the current political system. This history might be relevant in unstable environments, especially when there was a substantial prior record of limited government.

12 Przeworski and Limongi (1997) point out, contrary to modernization theory, that the positive association between democracy and economic development can be due to an exogenous explanation: even though democracies are established independently of economic development, they are more likely to survive in developed countries. They do not explore the causality from political development to economic development. 
longest record of limited government. This evidence indicates that political stability per se is no guarantee of economic development, but that limited government plus political stability is indeed a path that leads to economic development. Having moderate government might be like growing wiser with age: that happens only if you are able to learn from experience. The group of countries with the highest income per capita, a group that roughly coincides with OECD countries, has had limited government for longest. This institutional structure of power sharing might also facilitate learning at the society-wide level.

The results on the positive effects of polity persistence on economic development when there are high political constraints can be contrasted to Clague, Keefer, Knack and Olson (1996), who distinguish between democracies and autocracies. They establish that there is a strong relationship between the length of time a democratic system has lasted and the security of property and contract rights in a society. As to autocracies, they also find that the longer the tenure of an autocrat, the better the contract and property rights.

However, there is a fundamental difference between autocracy and stable democracy over the long run. In an autocracy, men govern without institutions, so the system has to start anew with each successor. In this regard, Olson (2000, p. 43) recognizes that countries that have enjoyed good economic performance across generations are not dictatorships, but rather stable democratic governments. Olson (2000, p. 41) also establishes a connection between lasting democracy and property rights important for economic progress, because a viable democracy requires the rights of the opposition, including free speech as well as contract and property rights, to be respected. If even the opposition has these rights, other citizens will also have them.

Our econometric evidence is close in spirit to the ideas in Olson (2000), and extends the view in North and Thomas (1973) that, from a historical viewpoint, the emergence of limited government in England and the Netherlands was the path to the industrial revolution and sustained economic growth in the West. This view of economic development as a consequence of limited government is also at the heart of Montesquieu's work in the Spirit of the Laws.

\section{REFERENCES}

Aron, Janine (2000). "Growth and institutions: A review of the evidence”, World Bank Research Observer, Vol. 15; 99-135.

Barro, Robert and Xavier Sala-i-Martin (1995). Economic Growth, New York: McGraw-Hill.

Beck, Thorsten, Asli Demirgüç-Kunt and Ross E. Levine (2001). "Law, politics, and finance", mimeo, World Bank and University of Minnesota.

Burki, Shahid and Guillermo Perry (1998). Beyond the Washington Consensus: Institutions Matter, Washington: World Bank.

Clague, Christopher, Philip Keefer, Stephen Knack and Mancur Olson (1996). "Property and contract rights in autocracies and democracies", Journal of Economic Growth, Vol. 1; 243-276.

Coase, Ronald (1960). "The problem of social cost", Journal of Law and Economics, Vol. 3; 1-44. 
Drelichman, Mauricio, (2001). "Law, institutions and growth. A semiparametric study", mimeo, Northwestern University.

Gaviria, Alejandro, Ugo Panizza, Jessica Seddon and Ernesto Stein (1999). "Political institutions and economic outcomes", mimeo, Inter-American Development Bank.

Gurr, Ted R. (1989), Polity II: Political Structures and Regime Change, 1800 1986, Boulder, CO: Center for Comparative Politics, and Ann Arbor, MI: ICPSR.

Henisz, Witold J. (2000). "The institutional environment for economic growth", Economics and Politics, Vol. 12; 1-31.

Hirschman, Albert O. (1996) [1976]. The Passions and the Interests. Political Arguments for Capitalism before its Triumph, Princeton: Princeton University Press.

La Porta, Rafael, Florencio López-de-Silanes, Andrei Shleiffer, and Robert Vishny (1997). "Legal determinants of external finance", Journal of Finance, Vol. 52, 1131-1150.

Montesquieu (1989) [1748]. The Spirit of the Laws, Cambridge: Cambridge University Press.

Nino, Carlos S. (1996). The Constitution of Deliberative Democracy, New Haven: Yale University Press.

North, Douglass (1981). Structure and Change in Economic History, New York: Norton \& Co.

North, Douglass (1990). Institutions, Institutional Change and Economic Performance, Cambridge: Cambridge University Press.

North, Douglass and Robert Thomas (1973). The Rise of the Western World: A New Economic History, Cambridge: The University Press.

North, Douglass and Barry Weingast (1989). "Constitutions and commitment: The evolution of institutions governing public choice in seventeenthcentury England", Journal of Economic History, Vol 49; 803-832.

Olson, Mancur (1996). "Big bills left on the sidewalk: Why some nations are rich, and others poor", Journal of Economic Perspectives, Vol. 10; 3-24.

Olson, Mancur (2000). Power and Prosperity. Outgrowing Communist and Capitalist Dictatorships, New York: Basic Books.

Przeworski, Adam and Fernando Limongi (1997). "Modernization: Theories and facts", World Politics, Vol. 49; 155-183.

Rice, John A. (1995). Mathematical Statistics and Data Analysis, Belmont, CA: Duxbury Press.

Smith, Adam (1976) [1776]. The Wealth of Nations, Chicago: University of Chicago Press.

Streb, Jorge M. (2001). "Political uncertainty and economic underdevelopment", Estudios de Economia, Vol. 28; 89-114.

Tucker, Robert C., editor (1972). The Marx - Engels Reader, New York: Norton. 